\section{Fusion of Yeast Protoplasts ${ }^{\dagger}$}

\section{Masahiro Yамамото and Sakuzo FukuI}

The Institute of Applied Microbiology, The University of Tokyo, Tokyo, Japan Received July 4, 1977

Recently, we found the papers described the fusion of spheroplasts of Saccharomyces cerevisiae. $^{1,2)}$ However, independently, we have also studied the asexual cell fusion of the microorganism by applying protoplastsystem. In this paper, we present a technique for fusion of the protoplasts prepared from the same mating type cells of auxotrophs; Saccharomyces cerevisiae 156-5C (a gal5 hisl) and G4-a (a gal3 met1 ural ade6), these were obtained from the Yeast Genetic Stock Center, University of California, U. S. A.

The cells of the auxotrophs were separately cultured in $100 \mathrm{ml}$ of YPG medium $(0.4 \%$ yeast extracts, $0.5 \%$ peptone, $5 \%$ glucose, $0.5 \% \mathrm{KH}_{2} \mathrm{PO}_{4}$ and $0.2 \% \mathrm{MgSO}_{4} 7 \mathrm{H}_{2} \mathrm{O}$ ) without shaking at $30^{\circ} \mathrm{C}$ and harvested at an early log-growth phase (approximately $1 \times 10^{8}$ cells $/ \mathrm{ml}$ ) by centrifugation. The cells were suspended in $2 \mathrm{ml}$ of SET medium $(1.3 \mathrm{M}$ sorbitol, $0.1 \mathrm{~mm}$ EDTA and $10 \mathrm{~mm}$ Tris- $\mathrm{HCl}$ buffer, $\mathrm{pH}$ 7.4). To the cell suspension were added $0.1 \mathrm{ml}$ of $\beta$-mercaptoethanol and $0.1 \mathrm{ml}$ of $0.1 \mathrm{M}$ EDTA solution, then incubation was performed at $30^{\circ} \mathrm{C}$ for $30 \mathrm{~min}$. The cells were collected and resuspended in $2 \mathrm{ml}$ of SET medium. The cell suspensions of both strains were mixed, and immediate addition of Zymolyase (High Grade 60,000, Kirin Brewery, Japan) was conducted to the mixed suspension (final enzyme concentration, $250 \mu \mathrm{g} / \mathrm{ml}$ ), followed by incubation at $30^{\circ} \mathrm{C}$ for $3 \mathrm{hr}$. The protoplasts thus formed (Micrograph 1) were collected by centrifugation $(10,000 \times g)$ and suspended in fusion medium ( $40 \%$ polyethylene

* This report is a part of Master Thesis of M. Yamamoto (accepted Feb. 10th, 1977, University of Tokyo).

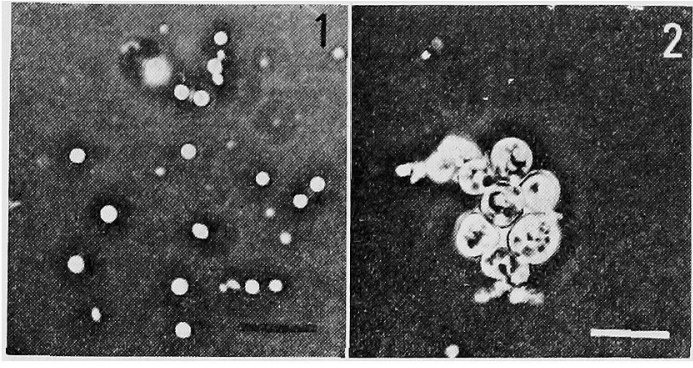

Micrograph 1. Protoplasts before Fusion Process, Mixture of 156-5C and G4-a.

Micrograph 2. Protoplasts after Fusion Process (overnight), Mixture of $156-5 \mathrm{C}$ and G4- $a$.

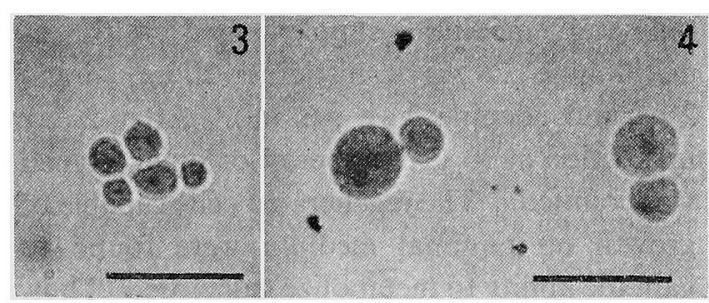

Micrograph 3. Nuclei in $156-5 \mathrm{C}$ Cells. Similar micrograph was obtained with G4- $a$ cells.

Micrograph 4. Nuclei in "Hybrid" Cells (F-3). Bars in micrographs are $10 \mu \mathrm{m}$. Nuclei were stained with Giemsa reagent. ${ }^{5)}$

glycol 6,000 (PEG), $0.75 \mathrm{M}$ sorbitol, $5 \%$ glucose, $50 \mathrm{mM} \mathrm{CaCl}$ and $50 \mathrm{~mm}$ Tris- $\mathrm{HCl}$ buffer, $\mathrm{pH}$ 7.4) to bring to a protoplast concentration of approximately $2 \times 10^{9} / \mathrm{ml}$. Incubation was carried out at $37^{\circ} \mathrm{C}$ for $30 \mathrm{~min}$ (Fusion Process). Then, the protoplasts were collected by centrifugation $(10,000 \times g)$, and resuspended in $2 \mathrm{ml}$ of fusion medium with omission of PEG. For regeneration of the protoplasts to vegetative cells, ${ }^{3)} 0.1 \mathrm{ml}$ of the suspension was mixed with $10 \mathrm{ml}$ of a hypertonic YPG medium $(0.75 \mathrm{~m}$ sorbitol and $30 \%$ gelatin (Difco) in YPG medium) and immediately poured into petri dish (at $45^{\circ} \mathrm{C}$ ), then incubation was performed at $30^{\circ} \mathrm{C}$ for one day. To the petri dish was added $1.0 \mathrm{ml}$ of gelatinase solution (Tokyo Kasei, $10 \mathrm{mg} / \mathrm{ml}$ ) to solubilize gelatin in the medium. The regenerated cells in the solubilized medium were collected, diluted with saline and plated onto both minimal medium $(5 \%$ glucose, $0.3 \% \quad\left(\mathrm{NH}_{4}\right)_{2} \mathrm{SO}_{4}, \quad 0.1 \% \quad \mathrm{KH}_{2} \mathrm{PO}_{4}, \quad 0.05 \%$ $\mathrm{MgSO}_{4} \cdot 7 \mathrm{H}_{2} \mathrm{O}, \quad 0.01 \% \quad \mathrm{CaCl}_{2} \cdot 2 \mathrm{H}_{2} \mathrm{O}, \quad 0.01 \%$ 
TAble 1. Frequencies of "Hybrid" Formation by Fusion-Regeneration Process from Protoplasts of Saccharomyces cerevisiae

\begin{tabular}{ll}
\hline \multicolumn{1}{c}{ Strains } & Frequencies $^{a)}$ \\
\hline $\mathrm{G} 4-\mathrm{a}+156-5 \mathrm{C}$ & $3.0 \times 10^{-7}$ \\
$\mathrm{G} 4-\mathrm{a}$ & less than $10^{-9}$ \\
$156-5 \mathrm{C}$ & less than $10^{-9}$ \\
$\mathrm{G} 4-\mathrm{a}+156-5 \mathrm{C}^{b)}$ & less than $10^{-9}$ \\
\hline
\end{tabular}

a) colony number on minimal medium/colony number on supplemented medium (see text)

b) PEG- or/and $\mathrm{Ca}^{2+}$-free fusion media were used.

$\mathrm{NaCl}$ and vitamines*) and supplemented one (minimal medium supplemented with Lmethionine $20 \mu \mathrm{g}$, L-histidine $20 \mu \mathrm{g}$, uracil $2 \mu \mathrm{g}$ and adenine $2 \mu \mathrm{g}$ per $\mathrm{ml}$ ). After 2-day incubation at $30^{\circ} \mathrm{C}$, number of colonies formed was counted. The regenerated cells capable of growth on minimal medium were found to gain the ability to metabolize galactose. Thus, we would like to designate these cells as "hybrid" cells or the "asexually induced hybrid" cells in this paper. A frequency of the "hybridization" is approximately $3.0 \times$ $10^{-7}$ (Table I). When $\mathrm{Ca}^{2+}$ ions and/or PEG were removed from fusion medium, the frequencies decrease to negligible level. Deoxyribonucleic acid (DNA) content in a cell of the "hybrid" was higher than that in a cell of haploid strains used here (Table II). Morphological properties of the "hybrid" cells were somewhat different from those of the haploid cells; the "hybrid" cells are larger in size and less-aggregative in mass behavior in liquid culture.

During fusion process $(30 \mathrm{~min})$ it was very hard to obtain clear evidence supporting occurrence of protoplast fusion as morphological alteration. However, formation of monster protoplasts could be observed by prolongation of fusion process, such as overnight incubation (Micrograph 2). Both $\mathrm{Ca}^{2+}$ ions and PEG were essentially required for formation of monster protoplasts. In Micrographs 3 and 4 , nuclear staining was carried out with haploid (156-5C) and "hybrid" (F-3, see Table II) cells, respectively. From these micrographs, however, the determinative information about ploidy of the "hybrid" cell was not available. Genetical properties of the "hybrid" cells are under investigation.

Acknowledgement. This investigation was supported in part by a research grant from the Ministry of Education of Japan.

\section{REFERENCES}

1) A. Svoboda, Folia Microbiol. (Prague), 21, 193 (1976).

2) P. van Solingen and J. B. van der Plaat, J. Bactriol., 130, 946 (1977).

3) A. Svoboda, Exp. Cell. Res., 44, 640 (1966).

4) W. C. Schneider, J. Biol. Chem., 161, 293 (1945).

5) C. F. Robinow, "Methods in Cell Biology XI, Yeast Cells," ed. by D. M. Prescott, Academic Press, New York, San Francisco and London, 1975 , p. $1 \sim 22$.

Table II. Deoxyribonucleic Acid Content in Yeast Cell

Diploid strain was obtained from haploid strains of $156-5 \mathrm{C}$ and $\mathrm{G} 4-\alpha$. $F-1$ to $\mathrm{F}-7$ were randomly picked-up strains from the hybrids isolated in this paper.

\begin{tabular}{lcccccccccc}
\hline Strain & $156-5 \mathrm{C}$ & $\mathrm{G} 4-a$ & Diploid & $\mathrm{F}-1$ & $\mathrm{~F}-2$ & $\mathrm{~F}-3$ & $\mathrm{~F}-4$ & $\mathrm{~F}-5$ & $\mathrm{~F}-6$ & $\mathrm{~F}-7$ \\
\hline $\begin{array}{l}\text { Relative content of } \\
\text { DNA }\end{array}$ & $1.0^{\alpha)}$ & 0.9 & 1.9 & 3.1 & 1.9 & 1.8 & 1.4 & 1.8 & 1.2 & 1.6 \\
\hline
\end{tabular}

a) net content of DNA is $4.5 \mathrm{ng} / 10^{4}$ cells. This value was used as standard in this table. An amount of DNA was determined by the method of Schneider.4)

* Vitamines: biotin $20 \mu \mathrm{g}$, calcium pantothenate $2 \mu \mathrm{g}$, folic acid $2 \mathrm{ng}$, inositol $10 \mu \mathrm{g}$, nicotinic acid $0.4 \mu \mathrm{g}$. $p$-aminobenzoic acid $0.2 \mu \mathrm{g}$, pyridoxine- $\mathrm{HCl} 0.4 \mu \mathrm{g}$, rivoflavin $0.2 \mu \mathrm{g}$ and thiamine- $\mathrm{HCl} 0.4 \mu \mathrm{g}$ per ml. 